BBA $662 \mathrm{r} 3$

\title{
PORPHYRIN BIOSYNTHESIS
}

\section{AVIAN ERYTHROCYTE PORPHOBILINOGEN DEAMINASE- UROPORPHYRINOGEN III COSYNTHETASE, ITS PURIFICATION, PROPERTIES AND THE SEPARATION OF ITS COMPONENTS}

\author{
ELENA B. C. LLAMBÍAS and ALCIRA M. DEL C. BATLLE
}

Cátedra de Quimica Biológica I, Departamento de Quimica Biológica, Facultad de Ciencias Exactas $y$ Naturales, Perú 272, Buenos Aires (Argentina)

(Received July 9th, I970)

\section{SUMMARY}

I. A method for the isolation and purification of porphobilinogenase, porphobilinogen deaminase and uroporphyrinogen isomerase from avian erythrocytes is described.

2. Some properties of the isolated enzymes were studied. The optimal $\mathrm{pH}$ for porphobilinogenase and deaminase was 7.4. Purified porphobilinogenase was resolved into three bands on starch gel electrophoresis. The molecular weight of the purified enzymes was determined by gel filtration. The presence of porphobilinogen or $\mathrm{NH}_{4}{ }^{+}$ at certain concentrations afforded protection against heat inactivation of isomerase, the heat labile enzyme. Initial porphyrin formation by porphobilinogenase was linear with time.

3. The action of various compounds added to the system was studied. Thiol reagents inhibited both porphobilinogenase and deaminase, indicating the presence of thiol groups essential for activity. $\mathrm{NH}_{4}^{+}$, hydroxylamine, adenine, ADP, ATP, some dicarboxylic acids and 2 -methoxy-5-nitrotropone inhibited deaminase.

\section{INTRODUCTION}

The enzymic condensation of porphobilinogen into uroporphyrinogens has been described in various tissues ${ }^{1-12}$. It has been established that two enzymes are involved in this reaction, porphobilinogen deaminase and uroporphyrinogen III cosynthetase (also called isomerase). The two enzymes can be distinguished by their susceptibility to heat inactivation, porphobilinogen deaminase being heat stable whereas isomerase is unstable to heat. Deaminase alone converts porphobilinogen into uroporphyrinogen $\mathrm{I}$, in the presence of both deaminase and isomerase, uroporphyrinogen III being formed, but isomerasc alonc has no action on cither uroporphyrinogen I or porphobilinogen.

Abbreviation: PCMB, p-chloromercuribenzoate. 
The isolation and purification of porphobilinogenase ${ }^{1}$ and the separation of porphobilinogen deaminase from isomerase have been previously reported ${ }^{2-12}$. LockWOOD AND BENSON ${ }^{7}$, working with avian erythrocyles, found no evidence of more than one enzyme in such systems, as they failed to separate deaminase from isomerase by paper electrophoresis. However they postulated that the synthesis of uroporphyrinogen III is catalysed by two enzymes or by a single enzyme possessing both forms of activity. The present work describes the isolation and purification from avian erythrocytes of porphobilinogenase and the separation of its components deaminase and isomerase from each other. Some properties of the enzymes are also reported.

MATERIALS AND METHODS

Porphobilinogen was biosynthetically obtained ${ }^{13}$ and assayed by the method of MOOKE AND LABBE ${ }^{14}$. DEAE-cellulose for chromatography was obtained either from Sigma Chemicals or Schuchart (München). DEAE-cellulose columns were prepared as described by CoRNFORD ${ }^{8}$. Calcium phosphate gel was prepared according to KeIlin and HartreE ${ }^{15}$. Sephadex or Sepharose gels were obtained from Pharmacia, Uppsala, Sweden, and starch gel for electrophoresis from Connaught Medical Research Lab., Toronto, Canada. Tris- $\mathrm{HCl}$ and $\mathrm{Na}_{2} \mathrm{HPO}_{4}-\mathrm{NaH}_{2} \mathrm{PO}_{4}$ buffers were used throughout. All other reagents used were of A.R. grade obtained from several commercial sources. All solutions were made up in ion-free glass-distilled water.

Source material of enzymes. Chicken blood was obtained and collected as alrcady described ${ }^{\mathbf{1 6}}$.

Protein concentrations. Protein concentrations were determined using the Folin Ciocalteu reagen $\mathbf{t}^{17}$.

Estimation of enzyme activity. The standard incubation system contained, unless otherwise stated, the enzyme preparation (usually $2 \mathrm{ml}$ ) together with $0.05 \mathrm{M}$ Tris or phosphate buffer ( $\mathrm{pH} 7.4$ ), $30 \mu \mathrm{g}$ of porphobilinogen, $0.35 \mathrm{ml}$ of $1.7 \mathrm{M} \mathrm{NaCl}$ and $0.15 \mathrm{ml}$ of $0.12 \mathrm{M} \mathrm{MgCl}_{2}$, in a final volume of $3 \mathrm{ml}$ and at $\mathrm{pH} 7.4$. Incubations were carried out aerobically, in the dark, with mechanical shaking, at $38^{\circ}$ for $90 \mathrm{~min}$. When the effect of additives was studied, the incubation system contained only enzyme, substrate and buffer, with or without the addition of other reagents, in the same final volumc and $\mathrm{pH}$. Blanks were run with porphobilinogen and without enzyme. After incubation, trichloroacetic acid was added (to a final concentration of $5 \%, \mathrm{w} / \mathrm{v}$ ) to precipitate the protein, the mixture was exposed to light and air for 20-25 min to oxidize porphyrinogens, the precipitated protein was removed by filtration, and porphyrins formed or the remaining porphobilinogen were estimated in acid solution ${ }^{18}$. Porphyrins were fractionated and esterified by usual procedures ${ }^{16}$. Identification, quantitative determination of porphyrins formed and isomeric composition of uroporphyrin fractions were made by published methods ${ }^{19-21}$.

An enzyme unit was defined as the amount of enzyme that catalyses the formation of I nmole of uroporphyrinogen per $h$, under standard conditions, the specific activity being units of enzyme per $\mathrm{mg}$ of protein. For estimating isomerase activity, the reaction mixture was the same as described above, except that deaminasc was also added in the ratio $\mathrm{I} \mathrm{mg}$ of deaminase to $6 \mathrm{mg}$ of the isomerase preparation.

$\mathrm{NH}_{4}+$ that inhibit these enzymes $\mathbf{1}^{\mathbf{1 , 3 2 2 - 2 4}}$ should be removed from the enzyme preparations before the activity is estimated. This was carried out by molecular 
sieving with $2 \mathrm{~cm} \times 30 \mathrm{~cm}$ columns of Sephadex G-25, using $0.05 \mathrm{M}$ buffer $(\mathrm{pH} 7.4$ ) as eluant. When other gel columns were used, protein was eluted with the same buffers, and they were prepared as described by BATLLE et al. ${ }^{\mathbf{2 5}}$.

Fractions were automatically collected with an LKB collector (Stockholm). Molecular weights were estimated by gel filtration methods ${ }^{\mathbf{2 6 - 2 9}}$.

The procedure employed in starch gel electrophoresis was based on methods described by BODMAN ${ }^{30}$.

Separation of the enzymic protein fraction from haemcglobin was carried out by following essentially the procedure described by HENNESSEY et al. ${ }^{\mathbf{3 1}}$ but using a column of DEAE-cellulose instead of the treatment of the supernatant in tubes.

\section{RESULTS}

\section{Enzyme preparations}

All operations were carried out in the cold room at $4^{\circ}$, unless otherwise stated. The specific activities of the enzymes varied greatly from one experiment to another, but the relative results shown here were reproducible.

\section{Porphobilinogenase (Table I)}

The avian blood (approx. I l) was centrifuged, plasma and leucocytes were removed, and the cells were washed with $0.9 \% \mathrm{NaCl}$. The packed cells were mixed thoroughly with an equal volume of water, previously chilled to $o^{\circ}$, and periodically stirred for $60 \mathrm{~min}$ in an ice-bath (Table I, Step I). The avian erythrocyte haemolysate was centrifuged at $25000 \times g$ for $90 \mathrm{~min}$, and the sediment was discarded (Step 2). The $25000 \times g$ supernatant was filtered through filter paper and then placed on a column $\left(2 \mathrm{~cm} \times 5^{\circ} \mathrm{cm}\right)$ of DEAE-cellulose previously equilibrated with $0.003 \mathrm{M}$ phosphate buffer $(\mathrm{pH} 7.4)$. The column was washed thoroughly with the same buffer, the DEAE was then removed mechanically and the porphyrin-synthesizing system was desorbed from DEAE-cellulose as follows: $80-90 \mathrm{ml}$ of o.I34 M phosphate buffer

\section{TABLE I}

ISOLATION AND PURIFICATION OF PORPHOBILINOGENASE FROM AVIAN ERYTHROCYTES

Incubation conditions were as described in MATERIALS AND METHODS. Identification and quantitative determination of porphyrins formed and isomer analysis of uroporphyrin fraction were carried out by usual methods ${ }^{19-21}$. Protein concentrations were determined using the Folin Ciocalteu reagent ${ }^{17}$.

\begin{tabular}{|c|c|c|c|c|}
\hline Fraction & $\begin{array}{l}\text { Total } \\
\text { protein } \\
\text { (mg) }\end{array}$ & $\begin{array}{l}\text { Specific } \\
\text { activity } \\
\times 10^{3}\end{array}$ & $\begin{array}{l}\text { Purifi- } \\
\text { cation } \\
\text { (-fold) }\end{array}$ & $\begin{array}{l}\text { Porphyrins } \\
\text { formed } \\
\text { (\% type } \\
\text { III) }\end{array}$ \\
\hline I. Haemolysate & 65000 & I.2 & $\mathbf{I}$ & I00 \\
\hline 2. $24000 \times g$ (supernatant) & r5 600 & 4.8 & 4 & IOo \\
\hline 3. DEAE-cellulose column & 700 & IOO & $83 \cdot 3$ & IOo \\
\hline 4. $0-90 \%$ satd. $\left(\mathrm{NH}_{4}\right)_{2} \mathrm{SO}_{4}$ fraction & $\mathrm{I} 25$ & 542 & 451.6 & IOO \\
\hline 5. Supernatant from dialysis & 72 & 830 & 690 & IOO \\
\hline 6. $30-70 \%$ satd. $\left(\mathrm{NH}_{4}\right)_{2} \mathrm{SO}_{4}$ fraction & 58 & 1020 & 850 & IOO \\
\hline 7. $\mathrm{Ca}_{3}\left(\mathrm{PO}_{4}\right)_{2}$ gel treatment & $3^{8}$ & I 500 & 1250 & Ioo \\
\hline 8. Sephadex G-Ioo column (peak) & $3 \cdot 5$ & 5900 & 49 IO & IOO \\
\hline
\end{tabular}


( $\mathrm{pH}$ 7.4) was added to the adsorbent, and the mixture was stirred magnetically for $30 \mathrm{~min}$ in an ice-bath; the fluid supernatant was collected by centrifugation at $2000 \times g$ for Io $\mathrm{min}$; this step was repeated three times, and the supernatants were combined to yield the enzyme protein fraction. Buffer concentration was made $0.05 \mathrm{M}$ before the activity was estimated (Step 3). To the protein solution from Step 3, solid $\left(\mathrm{NH}_{4}\right)_{2} \mathrm{SO}_{4}$ was added to $90 \%$ saturation, and the $\mathrm{pH}$ was kept close to $\mathrm{pH} 7.4$ by the addition of concentrated ammonia. After the suspension had been stirred for $\mathrm{I} h$, the protein precipitate was collected by filtration and then dissolved in a small volume of $0.05 \mathrm{M}$ phosphate buffer ( $\mathrm{pH} \mathrm{7.4)} \mathrm{(Step} \mathrm{4).} \mathrm{Dialysis} \mathrm{of} \mathrm{the} \mathrm{protein}$ solution against glass-distilled water for $24 \mathrm{~h}$ produced a flocculent precipitate, which was centrifugcd and discarded (Step 5). This supernatant was then fractionated with $\left(\mathrm{NH}_{4}\right)_{2} \mathrm{SO}_{4}$; the fraction precipitating at $30-70 \%$ satn. was collected by centrifugation, dissolved in a small volume of $0.05 \mathrm{M}$ phosphate buffer ( $\mathrm{pH} \mathrm{7.4)}$ and passed through a Sephadex G-25 column (Step 6). The protein eluted was treated with calcium phosphate gel ( $3 \mathrm{mg}$ gel; I mg protein). After being stirred for Io min, the mixture was centrifuged at $2000 \times g$ for $5 \mathrm{~min}$, the supernatant was discarded, and the enzyme adsorbed on the gel was eluted successively with two portions of $3 \mathrm{ml}$ of $0.134 \mathrm{M}$ phosphate buffer. The two eluates were combined. Buffer concentration was made $0.05 \mathrm{M}$ before the activity was estimated (Step 7). The protein solution was concentrated by $\left(\mathrm{NH}_{4}\right)_{2} \mathrm{SO}_{4}$ precipitation and applied to a Sephadex G-Ioo column (Step 8). Fig. Ia shows a typical elution diagram. Porphobilinogenase activity was associated with the second protein band.

\section{Deaminase (Table II)}

Steps I-6 were the same as those described for porphobilinogenase. In Step 7 the protein solution from Step 6 was concentrated by $\left(\mathrm{NH}_{4}\right)_{2} \mathrm{SO}_{4}$ precipitation and desalted with Sephadex G-25. The eluate was heated with continuous stirring at $60^{\circ}$ for $15 \mathrm{~min}$, immediately cooled in an ice-bath and centrifuged; the precipitate was

\section{TABLE II}

ISOLATION AND PURIFICATION OF DEAMINASE FROM AVIAN ERYTHROCYTES

Inculation conditions were as described in MATERIALs AND METHODs. Identification and quantitative determination of porphyrins formed and isomer analysis of uroporphyrin fraction were carried out by usual methods ${ }^{\mathbf{1 9}-21}$. Protein concentrations were determined using the Folin Ciocalteu reagent ${ }^{17}$.

\begin{tabular}{|c|c|c|c|c|c|}
\hline \multirow[t]{2}{*}{ Fraction } & \multirow{2}{*}{$\begin{array}{l}\text { Total } \\
\text { protein } \\
\text { (mg) }\end{array}$} & \multirow{2}{*}{$\begin{array}{c}\text { Specific } \\
\text { activity } \\
\times T 0^{3}\end{array}$} & \multirow[t]{2}{*}{$\begin{array}{l}\text { Purifi- } \\
\text { cation } \\
\text { (-fold) }\end{array}$} & \multicolumn{2}{|c|}{$\begin{array}{l}\text { Porphyrins formed } \\
(\%)\end{array}$} \\
\hline & & & & Type I & Type III \\
\hline I. Haemolysate & 65000 & 1.2 & $\mathbf{I}$ & & IOO \\
\hline $2.24000 \times g$ (supernatant) & I 5600 & 4.8 & 4 & & IOO \\
\hline 3. DEAE-cellulose column & 700 & 100 & $83 \cdot 3$ & & IOO \\
\hline 4. o- $90 \%$ satd. $\left(\mathrm{NH}_{4}\right)_{2} \mathrm{SO}_{4}$ fraction & 125 & 542 & $45 \times .6$ & & IOO \\
\hline 5. Supernatant from dialysis & 72 & 830 & 690 & & IOO \\
\hline 6. $30-70 \%$ satd. $\left(\mathrm{NH}_{4}\right)_{2} \mathrm{SO}_{4}$ fraction & $5^{8}$ & 1020 & 850 & & IOo \\
\hline 7. Heat treatment & 25 & $435^{\circ}$ & 4100 & 85 & I5 \\
\hline 8. Second $70 \%$ satd. $\left(\mathrm{NH}_{4}\right)_{2} \mathrm{SO}_{4}$ fraction & I6.7 & 6300 & 6050 & 90 & IO \\
\hline 9. Sephadex G-I oo column (peak) & 3 & 8900 & $855^{\circ}$ & 100 & \\
\hline
\end{tabular}


discarded. In Step 8 the supernatant was made to $70 \%$ satn. with $\left(\mathrm{NH}_{4}\right)_{2} \mathrm{SO}_{4}$, the precipitate was collected by centrifugation and dissolved in a small volume of $0.05 \mathrm{M}$ phosphate buffer ( $\mathrm{pH}$ 7.4). In Step 9 the protein solution was applied to a Sephadex G-IOo column. Fig. Ib despicts a typical elution diagram. Deaminase was associated with the second protein band.

\section{Isomerase (Table III)}

Steps I-4 were the same as those described for porphobilinogenase. The protein solution from Step 4 was desalted with Sephadex G-25, the eluate was fractionated with $\left(\mathrm{NH}_{4}\right)_{2} \mathrm{SO}_{4}$ to $80-90 \%$ satn., and the precipitate was then dissolved in a small volume of $0.05 \mathrm{M}$ phosphate buffer ( $\mathrm{pH}_{7.4}$ ) (Step 5). The protein solution was applied

\section{TABLE III}

ISOLATION OF ISOMERASE FROM AVIAN ERYTHROCYTES

For the estimation of isomerase activity (Steps $5 \mathrm{a}$ and $6 \mathrm{a}$ ), incubation conditions were the same as described in MATERIALS AND METHODS except that 60oo-fold purified deaminase was used (I $\mathrm{mg}$ of deaminase $5 \mathrm{mg}$ of isomerase). As the exact isomerase/deaminase ratio in the haemolysate and supernatant is not known, results cannot be expressed in terms of specific activity of isomerase. Identification and quantitative determination of porphyrins formed and isomeric analysis of uroporphyrin fraction were carried out by usual methods ${ }^{19-21}$.

\begin{tabular}{|c|c|c|}
\hline \multirow[t]{2}{*}{ Fraction } & \multicolumn{2}{|c|}{ Porphyrins formed } \\
\hline & Type I & Type III \\
\hline \multirow{8}{*}{$\begin{array}{l}\text { I. Haemolysate } \\
\text { 2. } 24 \text { ooo } \times g \text { (supernatant) } \\
\text { 3. DEAE-cellulose column } \\
\left.\text { 4. o-90\% satd. ( } \mathrm{NH}_{4}\right)_{2} \mathrm{SO}_{4} \text { fraction } \\
\text { 5. } 80-90 \% \text { satd. }\left(\mathrm{NH}_{4}\right)_{2} \mathrm{SO}_{4} \text { fraction } \\
\text { 5a. } 80-90 \% \text { satd. }\left(\mathrm{NH}_{4}\right)_{2} \mathrm{SO}_{4} \text { fraction }+ \text { deaminase } \\
\text { 6. Sephadex G-Ioo column (pooled fractions) } \\
\text { 6a. Sephadex G-Ioo column (pooled fractions) }+ \\
\text { deaminase }\end{array}$} & $\ldots$ & IOO \\
\hline & - & IOO \\
\hline & - & IOO \\
\hline & 一 & IOO \\
\hline & - & - \\
\hline & IO-O & $90-100$ \\
\hline & - & - \\
\hline & IO-O & $90-100$ \\
\hline
\end{tabular}

to a Sephadex G-Ioo column (Step 6). Fig. Ic shows a typical elution diagram; isomerase was associated with the first protein peak.

Alternatively, isomerase was prepared by a simpler procedure in the following manner. The 25 ooo $\times g$ supernatant obtained after Step 2 of the general purification, was applied to a Sephadex G-Ioo column $(2.5 \mathrm{~cm} \times 80 \mathrm{~cm})$. The first protein peak, free of haemoglobin, had isomerase activity (Step 3). The pooled enzyme solution was fractionated with $\left(\mathrm{NH}_{4}\right)_{2} \mathrm{SO}_{4}$ to $80-90 \%$ satn. (Step 4 ), and rechromatographed on the same Sephadex G-IOo column (Step 5). Fig. Id shows the elution diagram, where again isomerase was associated with the first protein peak.

Gel filtration on Sephadex G-200, or Bio-gel P-30o instead of Sephadex G-Ioo, also purified the enzymes but did not further improve the purification, so Sephadex G-Ioo was the material adopted.

Attempts were also made to purify the enzymes by treatment with glacial acetic acid to $\mathrm{pH} 5.0$ and/or by the use of protamine sulphate, but these procedures were abandoned since they caused some inactivation of the enzymes.

Sometimes enzymes were prepared from acetone-dried powders of haemoly- 


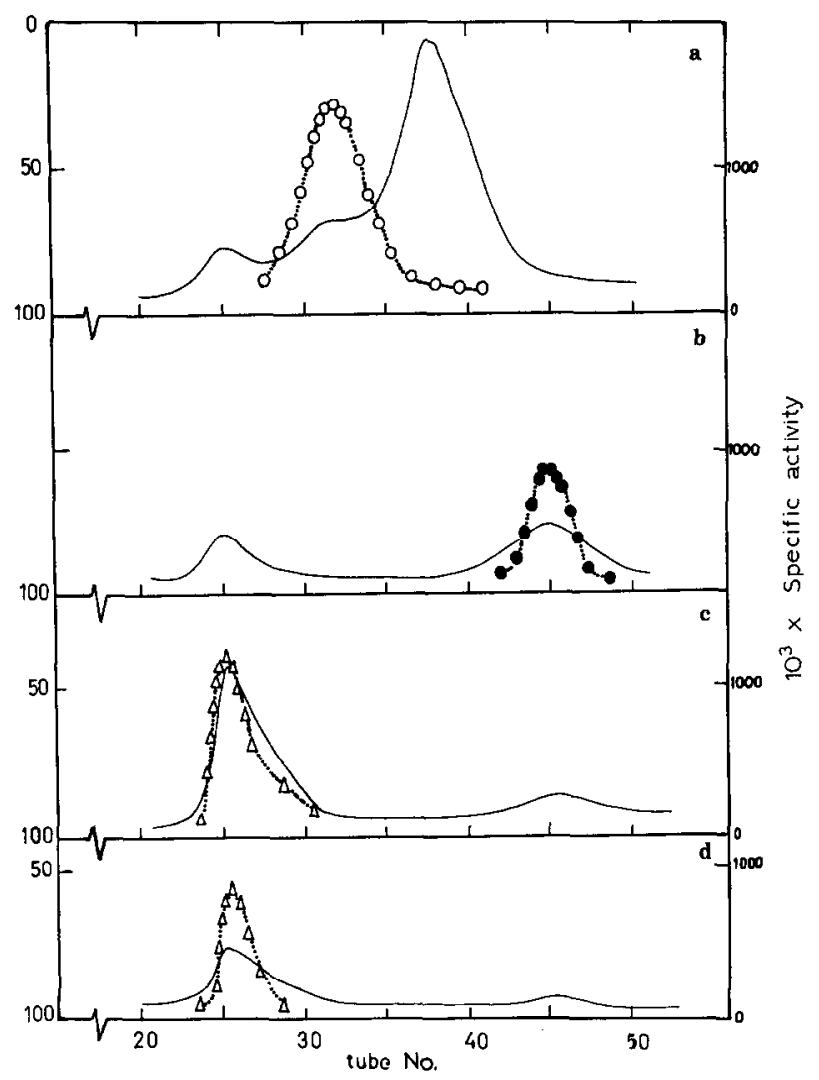

Fig. I. Elution diagram in a $2.5 \mathrm{~cm} \times 80 \mathrm{~cm}$ column of Sephadex G-Ioo of (a) porphobilinogenase, (b) deaminase, (c) and (d) isomerase preparations. (_-) ultraviolet absoption as recorded with a Uvicord $I ;(0 \cdots \cdots O)$ porphobilinogenase activity; $(0 \cdots \cdots)$ deaminase activity; $(\triangle \cdots \cdots \triangle)$ isomerase activity. Fractions of $4.3 \mathrm{ml}$ were collected. Activities were determined as described in MATERIALS AND METHODS.

sates, and these were obtained and extracted by the procedure of CORNFORD; the extracts were then worked up as described above.

\section{Properties}

Studies were performed with different enzyme preparations, but the results recorded here correspond to those obtained with I200-fold purified porphobilinogenase, 6ooo-fold purified deaminase, and isomerase after Step 5 of purification, unless otherwise stated.

Optimal activities of porphobilinogenase and deaminase were observed at $\mathrm{pH} 7.4$ in $0.05 \mathrm{M}$ phosphate buffer or $0.05 \mathrm{M}$ Tris buffer. The shapes of the curves were the same for both enzymes, and for both porphyrin formation and porphobilinogen consumption. The maxima found agree with those reported by LockwooD AND BENSON ${ }^{7}$. Under the standard conditions described, uroporphyrin formation increased linearly with time up to $6 \mathrm{~h}$, and there was no evidence of any lag. Porphobilinogen consumption was also linear. The amount of porphyrins formed was pro- 
portional to the concentration of enzyme over a wide range. The activity of both porphobilinogenase and deaminase was the same in the absence of oxygen as in its presence, as already reported ${ }^{7}$. Avian erythrocyte porphobilinogenase and deaminase were very stable at all stages of purification. $\left(\mathrm{NH}_{4}\right)_{2} \mathrm{SO}_{4}$ precipitated the enzyme in a form that was stable at $-\mathrm{I} 5^{\circ}$ for months.

\section{Effects of heat}

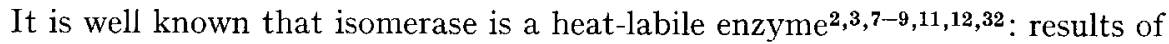
heat-treatment of the enzyme preparations from avian erythrocytes were similar to those previously reported. When heated at $60^{\circ}$ for $15 \mathrm{~min}$, porphobilinogenase appeared to be completely altered, giving only $15 \%$ of uroporphyrinogen III but significantly increasing total uroporphyrin formation (Table IV); this increase in activity

\section{TABLE IV}

\section{EFFECT OF HEAT ON ISOMERASE ACTIVITY}

Incubation conditions were as described in MATERIALS AND METHODS. Heated enzyme: the $30-70 \%$ satd. $\left(\mathrm{NH}_{4}\right)_{2} \mathrm{SO}_{4}$ fraction was desalted by gel filtration and then heated at $60^{\circ}$ for $\mathrm{I}_{5} \mathrm{~min}$; after cooling, the mixture was centrifuged at Io ooo $\times g$ for Io min and the precipitate was discarded. In Expts. 3 and 4 heating was performed in the presence of porphobilinogen or ammonium at the concentrations stated. Before the enzyme activity was estimated these compounds were removed from the mixture by gel filtration.

\begin{tabular}{|c|c|c|c|c|}
\hline \multirow[t]{2}{*}{ System } & \multirow[t]{2}{*}{ Addition } & \multirow{2}{*}{$\begin{array}{l}\text { Specific } \\
\text { activity } \\
\times r 0^{3}\end{array}$} & \multicolumn{2}{|c|}{$\begin{array}{l}\text { Uroporphyrin } \\
\text { formed }(\%)\end{array}$} \\
\hline & & & Type I & Type III \\
\hline I. $30-70 \%$ satd. $\left(\mathrm{NH}_{4}\right)_{2} \mathrm{SO}_{4}$ fraction & None & 1630 & - & 100 \\
\hline 2. Heated enzyme & None & 6769 & $8_{5}$ & I 5 \\
\hline 3. Heated enzyme & $\begin{array}{l}0.044 \mathrm{mM} \\
\text { porphobilinogen }\end{array}$ & 7700 & 60 & 40 \\
\hline 4. Heated enzyme & $\mathrm{IO}^{-} \mathrm{MHH}_{4}{ }^{+}$ & 6000 & - & IOO \\
\hline
\end{tabular}

was invariably found, and it agrees with the findings of other authors $7,8,12,32$. The sensitivity of the system to heating was influenced by the presence of porphobilinogen (Io $\mu \mathrm{g} / \mathrm{ml}$ ) or 0.0 I $\mathrm{M}$ ammonium which afforded protection against heat inactivation: ammonium gave I00\% protection. At higher temperatures there was a significant loss of activity.

\section{Estimation of molecular weights}

The weight-average molecular weights determined by gel filtration at various enzyme concentrations were estimated to be IIO $000 \pm$ IIOO for porphobilinogenase, $40000 \pm 4000$ for deaminase and $280000 \pm 28000$ for isomerase. The value obtained for isomerase is higher than that of the porphobilinogenase; therefore it is possible that, under the experimental conditions used, some association of various fractions of isomerase could have occurred. The use of calibrated Sepharose $6 \mathrm{~B}$ or $4 \mathrm{~B}$ columns in the presence of certain dissociating agents has provided some evidence of dissociation of the enzyme into fractions of mol. wt. 70 ooo (unpublished results), and experiments to obtain further evidence are in progress. 


\section{Electrophoresis}

Different enzyme preparations were subjected to electrophoresis on starch gel at different $\mathrm{pH}$ 's. At alkaline $\mathrm{pH}$ 's, the most highly purified porphobilinogenase resolved into three bands, while isomerase and deaminase migrated as a single band each (Fig. 2). Isomerase reached the same position as the second running band of porphobilinogenase, and deaminase behaved as the slower band. The electrophoretic migration rate of these preparations was compared with that of the same enzymes obtained from other sources; as is also shown in Fig. 2, some differences were observed.

\section{Isomer analysis of reaction products}

Preparations from different stages of purification of porphobilinogenase formed mainly uroporphyrinogen III, and the only product of the most highly purified deaminase preparations was uroporphyrinogen I. Isomerase obtained after $80-90 \%$ satn. with $\left(\mathrm{NH}_{4}\right)_{2} \mathrm{SO}_{4}$ or after Sephadex G-IOo, consumed no porphobilinogen and formed only uroporphyrinogen III when deaminase was added to the system.

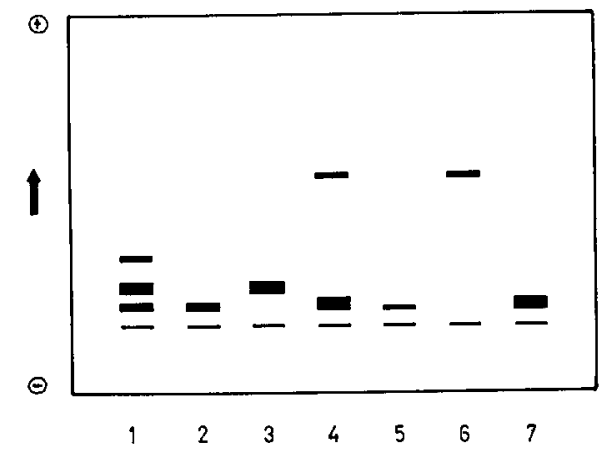

Fig. 2. Electrophoretic behaviour on starch gel of avian erythrocyte enzymes. (I) 490o-fold purified porphobilinogenase; (2) 8550 -fold purified deaminase; (3) most highly purified isomerase; soybean callus enzymes ${ }^{12}$; (4) 7o-fold purified porphobilinogenase; (5) I 40 -fold purified deaminase; (6) most highly purified isomerase; (7) I 82-fold purified bovine liver porphobilinogenase (ref. i I and H. A. Sancovich, A. K. Rosenberg, A. M. Del C. Batlle And M. Grinstein, unpublished results). Borate buffer, $\mathrm{pH}$ 8.2. A current of $30 \mathrm{~mA}$ was passed for $4 \mathrm{~h}$ at room temperature.

\section{Conversion of a new pyrrol intermediate into uroporphyrinogens}

The formation of a pyrrolic intermediate resulting from the action of soybean callus porphobilinogenase on porphobilinogen has been reported ${ }^{33}$. It was found that this intermediate acted as the second substrate, with porphobilinogen, in the formation of uroporphyrinogen III by avian erythrocyte isomerase. When the intermediate was incubated with porphobilinogen and deaminase a mixture of $40 \%$ uroporphyrinogen I and $60 \%$ uroporphyrinogen III was formed. Soybean callus deaminase, acting on porphobilinogen, also produced a different pyrrolic intermediate ${ }^{33}$ which still behaved as a substrate for avian isomerase but with the formation of $67 \%$ uroporphyrinogen I and 33\% uroporphyrinogen III; while, in the presence of porphobilinogen and the avian deaminase, it formed only uroporphyrinogen I. 
TABLE V

EFFECT OF VARIOUS SUBSTANCES ON PORPHOBILINOGENASE AND DEAMINASE

Incubation conditions were as described in MATERIALS AND METHODS. The activity of the system in the presence of other reagents is expressed on the basis of porphyrin formed or porphobilinogen consumed as per cent of the controls. The substrate was added 5 min after the addition of the compound tested. Metal ions were tested as chlorides. Identification, quantitative determination of porphyrins and isomer analysis of uroporphyrin fraction were carried out by usual methods ${ }^{\mathbf{2 3 - 2 5}}$.

\begin{tabular}{|c|c|c|c|c|c|c|}
\hline \multirow[t]{2}{*}{ Additive } & \multirow{2}{*}{$\begin{array}{l}\text { Concn. } \\
(m M)\end{array}$} & \multicolumn{3}{|c|}{ Porphobilinogenase rate } & \multicolumn{2}{|c|}{ Deaminase rate } \\
\hline & & $\begin{array}{l}\text { Porphyrin } \\
\text { formation }\end{array}$ & $\begin{array}{l}\text { Porphobi- } \\
\text { linogen } \\
\text { consump- } \\
\text { tion }\end{array}$ & $\begin{array}{l}\text { Isomer } I I I \\
(\%)\end{array}$ & $\begin{array}{l}\text { Porphyrin } \\
\text { formation }\end{array}$ & $\begin{array}{l}\text { Porphobi- } \\
\text { linogen } \\
\text { consump- } \\
\text { tion }\end{array}$ \\
\hline Cysteine & o. I & 87 & 89 & 43 & 77 & I08 \\
\hline Iodosobenzoate & I & 5 & 45 & - & 5 & 44 \\
\hline \multirow[t]{3}{*}{ PCMB } & $0 . I$ & I & 57 & - & 5 & 45 \\
\hline & $\mathbf{I}$ & $\mathbf{I}$ & 20 & - & 3 & Io \\
\hline & I & & & & & \\
\hline PCMB + Cysteine & I & 2 & 32 & - & 23 & 88 \\
\hline РCMB & $\mathbf{I}$ & & & & & \\
\hline PCMB + Cysteine & 5 & 80 & 90 & IOO & 98 & 100 \\
\hline DTNB & $\mathbf{I}$ & $5^{8}$ & $8 \mathrm{I}$ & I 3 & 18 & 74 \\
\hline $\mathrm{CN}$ & $\mathbf{I}$ & 96 & 100 & 20 & I0O & 100 \\
\hline Thiourea & $\mathbf{I}$ & 59 & 98 & 100 & I I 4 & 98 \\
\hline $\mathrm{SO}_{3}^{2-}$ & I & $5^{8}$ & 99 & 100 & 74 & 106 \\
\hline \multirow[t]{2}{*}{$\mathrm{F}^{-}$} & $\mathbf{I}$ & 89 & I0O & 80 & 98 & IOO \\
\hline & Io & 85 & 96 & - & 92 & 95 \\
\hline \multirow[t]{2}{*}{$\mathrm{NaN}_{3}$} & I & Io8 & 69 & 100 & 105 & 64 \\
\hline & IO & 86 & 96 & 100 & 107 & 80 \\
\hline \multirow[t]{3}{*}{ Hydroxylamine } & I & $5 \mathrm{I}$ & 82 & IOO & 100 & IOO \\
\hline & IO & $4^{2}$ & 82 & IOO & 53 & 102 \\
\hline & IOO & 8 & 80 & roo & $4^{I}$ & 100 \\
\hline \multirow[t]{3}{*}{$\mathrm{NH}_{4}^{+}$} & IO & 95 & 96 & 100 & 64 & 94 \\
\hline & IOO & 38 & 80 & IOo & $9^{8}$ & 94 \\
\hline & 200 & $2 \mathrm{I}$ & 62 & IOO & - & - \\
\hline \multirow[t]{2}{*}{ Adenine } & I & 62 & 92 & IOO & $7 \mathrm{I}$ & 97 \\
\hline & Io & $4^{I}$ & 76 & IOO & 26 & 99 \\
\hline ATP & 5 & 16 & 65 & 一 & 6 & 64 \\
\hline $\mathrm{ADP}$ & 5 & 28 & 70 & IOO & 3 & 64 \\
\hline \multirow[t]{2}{*}{ Succinic acid } & $\mathbf{I}$ & 80 & 80 & IOO & 77 & 94 \\
\hline & Io & 85 & 80 & 63 & 80 & 99 \\
\hline Phthalic acid & I & 67 & 97 & IOO & 70 & 100 \\
\hline \multicolumn{7}{|l|}{ 2-Methoxy-5-nitro- } \\
\hline tropone & $\mathbf{I}$ & $7^{\circ}$ & 90 & 60 & o & 100 \\
\hline $\mathrm{Hg}^{2+}$ & 0.01 & 0 & 5 & - & 5 & IO \\
\hline \multirow[t]{3}{*}{$\mathrm{Zn}^{2+}$} & $0.0 I$ & I 5 & 35 & - & 20 & 60 \\
\hline & $0 . I$ & 34 & 72 & 80 & 39 & 100 \\
\hline & $\mathbf{I}$ & I I & 98 & 40 & 63 & 93 \\
\hline $\mathrm{Cd}^{2+}$ & $\mathbf{r}$ & 2 & 58 & - & $3 \mathbf{I}$ & 88 \\
\hline $\mathrm{K}^{+}$ & 100 & I IO & 66 & $5^{\circ}$ & 80 & 80 \\
\hline \multirow[t]{2}{*}{$\mathrm{Mg}^{2+}$} & $5^{\circ}$ & 68 & 90 & 100 & 67 & 96 \\
\hline & roo & 25 & 74 & $\cdots$ & 60 & 90 \\
\hline
\end{tabular}

Effect of various substances on enzyme activities (Table V)

Expcriments carried out with different enzyme preparations afforded essentially similar results. Those obtained with 6000 -fold purified deaminase and 850 -fold purified porphobilinogenase appear in Table $\mathrm{V}$, which shows the final concentration of additives to the reaction mixture. 
Cysteine at o.I $\mathrm{mM}$ produced slight inhibition of deaminase and isomerase, whereas I $\mathrm{mM}$ cysteine and other similar compounds tested were without effect.

Both enzymes were inhibited by some of the thiol reagents tested, and p-chloromercuribenzoate (PCMB) inhibition was reversed by cysteine. Thus the possibility of the existence of monothiol functional groups was clearly indicated.

Cyanide did not produce inhibition, but type I porphyrin was formed by porphobilinogenase, fluoride slightly inhibited isomerase, and thiourea and sulphite were also inhibitory, so the presence of vicinal dithiol groups was suggested.

Several nitrogen bases such as those listed in Table $\mathrm{V}$ were tested; Io $\mathrm{mM}$ sodium azide slightly inhibited porphobilinogenase and at I $\mathrm{mM}$ it seems to inhibit porphobilinogen consumption both for porphobilinogenase and deaminase. Hydroxylamine inhibited both porphobilinogenase and deaminase activities; however only isomer III was produced by porphobilinogenase, as if the inhibitory action were on the deaminase. $\mathrm{NH}_{4}{ }^{+}$at certain concentrations inhibited both deaminase and porphobilinogenase as expected; also ATP, ADP and adenine inhibited porphobilinogenase and deaminase but again porphobilinogenase formed only uroporphyrin III.

Deaminase activity was diminished by some dicarboxylic acids and by 2 methoxy-5-nitrotropone, a specific reagent for free amino groups of proteins ${ }^{34}$. Of these compounds, succinic acid at ro $\mathrm{mM}$ and nitrotropone also affected isomerase activity, but it is seen that porphobilinogen consumption seems not to be altered.

Metal ions such as $\mathrm{Hg}^{2+}, \mathrm{Zn}^{2+}$ and $\mathrm{Cd}^{2+}$ inhibited both enzymes. $\mathrm{K}^{+}$and $\mathrm{Na}^{+}$ in a wide range of concentrations seem to have no great effect, only slight activation occurring at noo $\mathrm{mM}$, but with $\mathrm{K}^{+}, 50 \%$ less isomer III was formed. $\mathrm{Mg}^{2+}$ inhibited both porphobilinogenase and deaminase above $50 \mathrm{mM}$.

\section{DISCUSSION}

LOckwOOD AND BENSON ${ }^{7}$ have claimed that in avian erythrocytes there was no independent deaminase, such as an enzyme associated with a heat-labile inhibitor. However they considered the possibility that the enzyme system responsible for the conversion of porphobilinogen into uroporphyrinogen III might be formed by two distinct enzymes, although they failed to show any evidence of the presence of two protein components. In this paper a method is reported for the purification from avian erythrocytes of porphobilinogenase and the separation of its components isomerase and deaminase from each other.

Isomerase was inactivated by heating the intact system at $60^{\circ}$ for $15 \mathrm{~min}$ : it is known to be more sensitive than the soybean isomerase ${ }^{12}$ which is only destroyed after heating at $70^{\circ}$ for $30 \mathrm{~min}$. As also reported for the latter enzyme ${ }^{12}$, heating increased 4 -fold the uroporphyrin synthesis, and the addition of o.or $\mathrm{M} \mathrm{NH}_{4}^{+}$or $0.044 \mathrm{mM}$ porphobilinogen afforded protection against heat inactivation. These findings suggest that isomerase could associate with the amino-methyl group of porphobilinogen, so when porphobilinogen or some amino derivative is present, it could bind the enzyme at the same site, thereby stabilizing it.

As has been previously reported ${ }^{7}$, the presence of monothiol groups in these enzymes is visualized although a mechanism for their participation cannot yet be postulated. They could stabilize the enzyme-substrate complex, or they might perhaps be indispensable to the enzymes by conferring on them a structural arrange- 
ment necessary for activity. It has been postulated that porphobilinogenase contains two or more interacting catalytic sites ${ }^{\mathbf{1 1}, 24}$, and that the conversion of porphobilinogen into uroporphyrinogens could occur in two steps ${ }^{\mathbf{1 2 , 3 3}}$, the first being the formation of an intermediate polypyrro ${ }^{33}$ and the second the final production of uroporphyrinogen from porphobilinogen and the polypyrrol. It may be that $-\mathrm{SH}$ groups are involved in these reactions. Thiol inhibitors affected to a different extent porphyrin formation and porphobilinogen consumption, being generally more inhibitory towards porphyrin formation, as if the second site were more sensitive. A study of the number and function of the -SH groups of these enzymes is being carried out.

The existence of dithiol groups essential for activity is also possible, because cyanide, sulphite or thiourea, reagents known to cleave disulphide bonds, sometimes caused partial inhibition. $\mathrm{CN}^{-}$, as already reported ${ }^{7}$, did not inhibit total porphyrin formation but in their presence, porphobilinogenase produced $80 \%$ uroporphyrinogen $\mathrm{I}$, as if cyanide interferes or competes with the substrate for isomerase.

$\mathrm{NH}_{4}{ }^{+}$and hydroxylamine inhibited porphobilinogenase and deaminase, and the same effect was observed with adenine, ATP and ADP. These results are different from those obtained for the same enzymes obtained from other sources (refs. II, I2, 24, and H. A. Sancovich, A. K. Rosenberg, A. M. Del C. Batlle and M. Grinstein, unpublishcd results). The results suggest that these compounds have scparate effects on deaminase and isomerase being greater on the deaminase. The inhibitory action could be due to a competition between the enzymes and the bases for their substrates, as proposed by CORNFORD ${ }^{8}$, SANCOVICH et al. ${ }^{11,24}$ and Llambías AND BATLLE ${ }^{12}$. These results also point to the idea that porphobilinogenase contains at least two active centres which are unequally affected by certain modifiers.

In addition, to see whether positively charged groups are involved in the attachment of the substrates to isomerase or deaminase, the effect of some dicarboxylic acids was examined. All of them inhibited deaminase between Io-30\%, only succinic acid at Io $\mathrm{mM}$ modified isomerase, but it is not known whether this inhibition has any significance. However, porphobilinogen consumption was not greatly affected, so it is also probable that dicarboxylic acids inhibit deaminase by competition with porphobilinogen or the polypyrrol intermediate for some positively charged groups on the enzyme, which could be amino groups as suggested by $\mathrm{TAIT}^{35}$. The possibility remains that the inhibitory effect was exerted on the substrate, but no evidence of such reaction could be obtained. However the great inhibition of deaminase by 2-methoxy-5-nitrotropone gave additional support to the first possibility.

Among several metals tested, $\mathrm{Hg}^{2+}, \mathrm{Zn}^{2+}$ and $\mathrm{Cd}^{2+}$ inhibited both enzymes, which could be due to combination between metal and some thiol groups on the enzynes.

On the basis of these results and other experimental evidence, a hypothetical scheme has been suggested for the enzymic synthesis of uroporphyrinogen from porphobilinogen ${ }^{12}$.

\section{ACKNOWLEDGEMENTS}

Part of this work was supported by the Consejo Nacional de Investigaciones Científicas y Técnicas, Buenos Aires, Argentina. One of the authors (A. M. del C. B.) is a member of the Career of Scientific Researchers in this Consejo. This work forms 
part of the thesis submitted by E. B. C. Ll. for the degree of Ph.D. to the University of Buenos Aires. Our thanks are due to Miss Hilda Gasparoli for her technical assistance.

\section{REFERENCES}

I W. H. Lockwood and C. Rimington, Biochem. J., 67 (I957) 8 P.

2 L. Bogorad, J. Biol. Chem., 233 (1958) 5or.

3 L. Bogorad, J. Biol. Chem., 233 (I958) 5 IO.

4 S. Granick and D. Mauzerall, J. Biol. Chem., 232 (I958) ixig.

5 H. Heath and D. S. Hoare, Biochem. J., 72 (I959) I4.

6 H. Heath and D. S. Hoare, Biochem. J., 73 (1959) 679.

7 W. H. Lockwood and A. Benson, Biochem. J., 75 (1960) 372.

8 P. CORNFORD, Biochem. J., 9 I (I964) 64.

9 E. Y. Levin and D. L. Coleman, J. Biol. Chem., 242 (I967) 4248.

io E. Stevens, R. B. Frydman and B. Frydman, Biochim. Biophys. Acta, I 58 (I968) 496.

i I H. A. Sancovich, A. M. Del C. Batlle and M. Grinstein, Biochim. Biophys. Acta, igi (I969) I 30.

i2 E. B. C. Llambias and A. M. Del C. Batlle, Biochem. J., I20 (1970), in the press.

i 3 H. A. Sancovich, A. M. Ferramola, A. M. Del C. Batlle and M. Grinstein, in H. Tabor AND C. TABor, Methods in Enzymology, Vol. I7, Academic Press, New York, 1970, p. 220.

I4 D. J. Moore and R. F. LabBe, Clin. Chem., io (1964) 1105.

I5 D. Keilin and E. F. Hartree, Biochem. $J$., 49 (I95I) 88.

I6 A. M. Del C. Batlle and M. Grinstein, Biochim. Biophys. Acta, 82 (I964) I.

i7 O. H. Lowry, N. J. Roserrough, A. L. Farr and R. J. Randat.t, J. Biol. Chem., i93 (I95I) 265.

I8 C. Rimington, Biochem. J., 75 (I960) 620.

i9 A. M. Del C. Batlle and M. Grinstein, Abstr. 8th Latinoam. Meeting Chem., Buenos Aives, 1962, P. 107.

20 P. Cornford and A. Benson, J. Chromatog., io (I963) I4I.

2 I A. M. Del C. Batlle And A. Benson, J. Chromatog., 25 (I966) il 7.

22 L. Bogorad, in S. P. Colowick and N. O. Kaplan, Methods in Enzymology, Vol. 5, Academic Press, New York, I962, p. 885.

23 L. Bogorad, Ann. N.Y. Acad. Sci., Iо 4 (1963) 676.

24 H. A. Sancovich, A. M. Del C. Batlle and M. Grinstein, FEBS Letters, 3 (I969) 223.

25 A. M. Del C. Batlle, A. Benson and C. Rimington, Biochem. $J ., 97$ (I965) 73 I.

26 P. ANDRews, Biochem. J., 91 (1964) 222.

27 P. ANDREws, Biochem. J., 96 (1965) 595.

28 A. M. DEL C. Batlle, J. Chromatog., 28 (1967) 82.

29 G. Locascio, H. A. Tigier and A. M. Del C. Batlle, J. Chromatog., 40 (I969) 453.

3o J. Bodman, in I. Sмітн, Chromatographic and Electrophovetic Techniques, Vol, 2. Interscience, New York, I960.

3i M. A. Hennessey, A. M. Waltersdorph, F. M. Huennekens and B. W. Gabrio, J. Clin. Invest., $4^{\mathrm{I}}$ (I962) $\mathrm{I} 257$.

32 H. L. Bool J And C. Rimington, Biochem. J., 65 (I957) 4.

33 E. B. C. Llambías and A. M. del C. Batlle, FEBS Letters, 6 (1970) 285.

34 H. Tamaoki, $J$. Biochem. Tokyo, 62 (I967) 7.

35 H. G. TAIT, in T. W. Goovwin, Porphyyin and Related Compounds, Academic Press, New York, I968, p. I9. 